\title{
LOW-TEMPERATURE STRESS TOLERANCE OF GRAPEVINE VARIETIES OF DIFFERENT ECOLOGICAL AND GEOGRAPHICAL ORIGIN
}

\author{
Nataliya I. Nenko\#, Irina A. Ilyina, Galina K. Kiseleva, \\ and Elena K. Yablonskaya \\ ${ }^{1}$ North Caucasian Regional Research Institute of Horticulture and Viticulture, 39, 40 let Pobedy Street, Krasnodar 350901, RUSSIA \\ \# Corresponding author, nenko.ncrrihv@bk.ru
}

Communicated by Dalija Segliṇa

\begin{abstract}
The cold-tolerance of 'Kristall' (Euro-Amur-American origin), 'Dostoyniy' and 'Krasnostop AZOS' (interspecific hybrids of Euro-American origin) grapevine varieties in the winter conditions of South Russia is characterised by the second (true dormancy) and third (induced dormancy) winter-resistance components. Here we used a complex approach to estimate plant adaptation to abiotic stress factors. We used the gravimetric method for humidity assessment and water content, spectral analysis for detection of the protein level and pigments and capillary electrophoresis to determine the level of carbohydrates, Krebs cycle organic acids, phenolcarbonic, ascorbic acids, and amino acids. The obtained results allow to suggest various mechanisms of adaptation of the studied varieties to the winter period stressors. The water content of shoots, levels of protein, amino acids, proline, sugars and the sum of phenolcarbonic acid and ascorbic acid are the most informative indicators of grape plants frost-resistance in the climate conditions of the Anapa-Taman region.
\end{abstract}

Key words: grapevine varieties, frost tolerance, metabolic evaluation, abiotic stress.

\section{INTRODUCTION}

In the context of global and regional climate change issues of plant resistance, including of grapes, to abiotic stress environment are of particular importance. The analysis of climatic changes over a long period indicates the emerging trend of manifestation of a sharp continental climate in the Cis-Caucasian Plain of South Russia: there have been significant changes in the timing and amplitude of climatic manifestations and their discrepancy with time intervals of phenophases of growth and development of grapes. Natural and climatic conditions of the North Caucasus region allow obtaining high yields of grapes that can withstand competition in the international market (Nenko et al., 2017; Yegorov et al., 2017). However, obtaining stable high yields is limited by the impact of adverse environmental factors such as winter frost (the second component of winter hardiness), especially after arid and hot summers, and return frosts after thaw (the third component of winter hardiness) (Nenko et al., 2017)
Understanding of the mechanisms of grapevine coldresistance to abiotic and biotic factors of the environment have relevance for the agricultural industry and biotechnology of highly productive grapevine varieties (Ollat et al., 2017; Nenko et al., 2017). The natural and climatic conditions of the South Russia can ensure high yields of grapevine, able to withstand market competition on a worldwide basis. However, stable high yields are restricted by the influence of unfavourable environmental factors, such as winter frosts, especially after long warm periods in summer. That is why only varieties with high productivity, good quality and adaptability to conditions of this region, can be successfully cultivated here on a sufficiently broad scale. This dictates the need for an improved range of varieties through the cultivation of grapevine varieties that are better adapted to the weather conditions of the region (Ferrandino and Lovisolo, 2014; Sha Valli Khan et al., 2014). A key issue of study of adaptation is to assess the potential genetically determined organism abilities in response to the action of unfavourable environmental factors (Nenko et al., 2017; Yegorov et al., 2017). 
Modern viticulture is characterised by an innovative focus of cultivation technologies, including the most important component - the variety that determines the stability and productivity of ampelocenosis.

The trend of intensification of viticulture, based on the management of productivity, accompanied by a change in the direction of selection in order to create new varieties is characterised by high technology, integrated stability, productivity and high-quality products. These requirements for varieties should be taken into account during hybridisation and be included in the breeding process, especially regarding donors and sources of valuable traits that will allow to obtain varieties with desired properties and significantly accelerate the breeding process.

The process of obtaining a new generation of grape varieties can significantly be accelerated by the use of, along with classical methods, modern DNA-marker technologies, molecular genetic and physiological and biochemical methods of evaluation of varieties and clones. The most important properties of varieties are high productivity, product quality and the ability to adapt to environmental stress factors. These properties are controlled by multidirectional genetic systems, which complicates the task. In this regard, the study of potential genetically determined capabilities of the genotype and their implementation in response to adverse environmental factors can solve this problem (Koshkin, 2010; Nenko et al., 2017).

The complex assessment of the grapevine varieties based on the physiological and biochemical indicators, which may be used as the indirect diagnostic techniques, permits to obtain more reliable characteristics of genotype resistance to unfavourable weather and climatic conditions (Xian et al., 2017; Arun-Chinnappa et al., 2017). In this regard, the study of physiological and biochemical mechanisms of grape adaptation that regulate the physiological processes, is especially topical.

The aim of this study was to determine the physiological and biochemical mechanisms of low-temperature resistance of grapevine varieties of different ecological and geographical origin, and identify varieties that have low-temperature resistance during the winter period, on the basis of metabolic evaluation of genotype expression, in the hydrothermal conditions of South Russia.

\section{MATERIALS AND METHODS}

The minimum temperature in the Anapa-Taman zone of South Russia in the winter of $2014-2015$ was $-7{ }^{\circ} \mathrm{C}$ in December $2014,-19{ }^{\circ} \mathrm{C}$ in January, $-11{ }^{\circ} \mathrm{C}$ in February, and precipitation was $81 \mathrm{~mm}, 73 \mathrm{~mm}$, and $15 \mathrm{~mm}$, respectively. The minimum air temperature in the winter of 2015-2016 was $-9{ }^{\circ} \mathrm{C}$ in December, $-13{ }^{\circ} \mathrm{C}$ in January, and $-5{ }^{\circ} \mathrm{C}$ in February, with precipitation of $28 \mathrm{~mm}, 118 \mathrm{~mm}$, and 47 $\mathrm{mm}$, respectively.
The study was conducted during the period from December to February of 2014-2016 in the territory of Anapa. During this period, there was an increase in the minimum air temperature in January and February by $6{ }^{\circ} \mathrm{C}$ and in precipitation by 45 and $32 \mathrm{~mm}$, respectively. During March of the same period, precipitation was $13 \mathrm{~mm}$, which is evidence of gradual warming conditions.

The research was conducted on the basis of the ampelographic collection of the Anapa Zonal Pilot Station of Viniculture and Wine-making, located in Anapa city, within the field of grape vine industrial varieties, on southern calcareous chernozem soils. The research was carried out using the equipment of the "Tool and Analytical" Centre of collective usage and physiology and biochemistry laboratory of the "North-Caucasian Federal Scientific Centre of Horticulture, Viniculture and Winemaking" (Nenko et al., 2017; Yegorov et al., 2017).

The plants originated in the same grafting year (1995), on parent stock Kober 5BB. Pruning for shape was a bilateral high-standard spiral cordon of the Anapa Zonal Pilot Station. Cultivation of grape was performed in a bare fallow with landing of $3 \times 2.5 \mathrm{~m}$. The objects of research were grape vine varieties of different ecological and geographic origin and maturation periods, which had survived the extreme temperatures in winter 2012.

The 'Kristall' variety, which has an early maturation period, was used as a control (interspecific hybrid of Euro-AmurAmerican origin). 'Dostoiniy' and 'Krasnostop' are medium maturation period varieties of the Anapa Zonal Pilot Station (interspecific hybrids of Euro-Amur-American origin) (Yegorov et al., 2017).

'Kristall' is a Hungarian breeding variety bred for the industrial purposes. The 'Kristall' parental pair is 'Amurskiy' $\times$ 'Csalloci Lojos' and 'Villar Blan' Hungarian variety. 'Kristall' is a high-productive variety characterised by very early maturation period and frost-resistance (up to $-27^{\circ} \mathrm{C}$ ). 'Kristall' grapes have yellowish-green colour and harmonious taste. Grape bunches of 'Kristall' have medium density, weighing 180-200 g. The sugar and acidity content ranges from 17 to $18 \%$ and from 6 to $7 \mathrm{~g} / \mathrm{l}$, respectively (Yegorov et al., 2017).

The 'Dostoiniy' variety was bred by the staff of the Anapa Zonal Pilot Station for industrial purposes. The parental pair is phylloxera-resistant 'Jemete' $\times$ 'Muscat' Hamburg. 'Dostoiniy' has a medium maturation period. It is Phylloxera-resistant and may be grown on its own roots, but it is highly susceptible to mildew and oidium. Grape bunches have a conical form with medium density and medium size. The taste is ordinary; its berries are used to prepare dry wines (Yegorov et al., 2017).

The 'Krasnostop AZOS' variety was also bred by Anapa Zonal Pilot Station breeders for industrial purposes and wine production. Its parental pair is Phylloxera-resistant 'Jemete' $\times$ 'Krasnostop Anapsky'. It has a medium early 
maturation period. On average the acidity of grapes juice is $8 \mathrm{~g} / \mathrm{l}$, and sugar content is $24 \%$. The form of 'Krasnostop AZOS' grapevines is cylindrical. Grape bunches have medium density and are small, about 120-130 g in weight (Yegorov et al., 2017). The grapevine samples were taken from five bushes of each variety.

All studies were conducted in three biological and three analytical repetitions.

To estimate the adaptation resistance of the grape plants to abiotic stress, we used the weight method (Kushnirenko and Pecherskaya, 1991) to determine total, free, and bound water content. To determine the content of free water, samples of shoots weighing $1 \mathrm{~g}$ each were dried in three replications for 24 hours in air, after which they were weighed. The content of free water was estimated by the loss in weight and expressed as percent of total water content. To determine the total content of water in the shoots, the $1 \mathrm{~g}$ weighed quantities were dried in three replications in thermostat until the weight becomes constant at $105{ }^{\circ} \mathrm{C}$. The water content of shoots was determined as difference between fresh weight of shoots and its dry mass. The content of bound water within the specimens was estimated as the difference between shoot total water content and free water content and expressed as a percentage of total water content.

The protein and pigment content was determined by a spectral method (Yermakov et al., 1972). To determine the protein content in the shoots, $1 \mathrm{~g}$ samples were analysed in three replications. The samples were ground in liquid nitrogen followed by protein extraction. For extraction of protein we used a buffer solution containing $0.48 \mathrm{mg} 0.1 \mathrm{M}$ Tris, $0.1 \mathrm{~g}$ ascorbic acid, $0.08 \mathrm{~g}$ ethylenediaminetetraacetate, 0.18 g sodium diethyldithiocarbamate, $0.145 \mathrm{~g}$ sodium chloride, $2.0 \mathrm{~g}$ polyethylenglycol, and distilled water in a total $100 \mathrm{ml}$ volume. The samples were homogenised and stored in a buffer for at least two hours. Then the samples were centrifuged in a cold $\left(+4{ }^{\circ} \mathrm{C}\right.$, centrifuge $5418 \mathrm{R}$ eppendorf $)$. The centrifugate was poured off into separate test glasses, and the precipitate was repeatedly topped up with the buffer. The extraction procedure was repeated three times. The precipitate of each replicate was combined in $100 \mathrm{ml}$ flasks with addition of a buffer to the mark. The obtained solution was poured into $10 \mathrm{~mm}$ thick quartz cells. The optical density of solutions was determined by an UNICO 2800 spectrophotometer at $280 \mathrm{~nm}$ wavelength. Finally, the protein content of specimen was determined by a calibration curve (Yermakov et al., 1972).

To estimate the content of pigments (anthocyanins, chalcons) in shoots $1 \mathrm{~g}$ samples were ground in liquid nitrogen, flooded with $10 \mathrm{ml}$ of $0.1 \mathrm{n}$ hydrochloric acid solution, infused in the cold for 1 hour and centrifuged. The extraction was performed three times. The supernatant was put into $100 \mathrm{ml}$ flasks, and $0.1 \mathrm{n}$ hydrochloric acid solution to the mark. Anthocyanin and chalcon contents were determined on LEKI SS1207 spectrophotometer at $490 \mathrm{~nm}$ and $364 \mathrm{~nm}$ wavelength, respectively (Yermakov et al., 1972).
The starch content was determined by polarimetric method on a universal polarimeter (Yermakov et al., 1972).

The level of carbohydrates (sucrose), Krebs cycle organic acids (malic, citric, succinic), phenolcarbonic acids (chlorogenic, caffeic), ascorbic acid, proline aminoacids, and metal cations ( $\mathrm{K}, \mathrm{Na}, \mathrm{Ca}, \mathrm{Mg}$ ) was determined by capillary electrophoresis. For this, $1 \mathrm{~g}$ samples was ground in three replications in liquid nitrogen, then put into a fluoroplastic container from a "Minotaur" microwave mineraliser, $25 \mathrm{ml}$ of $10 \%$ alcohol (ethanol 98\%) was added, and the container was placed into a mineralizer magnetron and processed for ten minutes in "pressureless decomposition" mode, applying $10 \%$ mineralizer magnetron capacity. After that the container was removed from microwave mineralizer, cooled in the natural conditions for five minutes and the obtained liquid was added to $25 \mathrm{ml}$ graduated flasks and made up to volume with the initial alcohol-water mixture (Kiseleva and Nenko, 2015; Yakuba et al., 2015).

Analysis of ascorbic, chlorogenic, caffeic acids was conducted using a Kapel $105 \mathrm{P}$ tool, equipped with a UV photometric detector, operating at $254 \mathrm{~nm}$ wavelength, quartz capillary at $0.5 \mathrm{~m}$ length at least to the detector, 50-100 $\mu \mathrm{m}$ inner diameter, positive polarity high-voltage source of variable voltage ranging from 1 to $25 \mathrm{kV}$ and personal computer with the relevant software for collection and processing of data. The contents of the analysed substances content were determined with the parameters as follows: positive voltage on capillary $-16 \mathrm{kV}$, time of analysis $-15 \mathrm{~min}$ utes for ascorbic, chlorogenic, caffeic acids. Calibration of contents was conducted by the standard addition method.

For organic acids (malic, citric, succinic) the operating parameters were: wavelength of spectrophotometric detector $-270 \mathrm{~nm}$, negative voltage $-25 \mathrm{kV}$, pneumatic dosage of sample at $30 \mathrm{mbar}$ for $5 \mathrm{~s}$ at $0 \mathrm{kV}$ voltage, time of analysis - 10 minutes. Samples electrophoregram values were within the range of calibration solution electrophoregram values. Calibration solutions were prepared by the standard addition method. The contents were determined using the following parameters: positive voltage on capillary $-10 \mathrm{kV}$, time of analysis - 40 minutes.

For the determination of amino acid content, to $0.05 \mathrm{ml}$ of extract was added $0.1 \mathrm{ml}$ of a $10 \%$ aqueous solution of sodium carbonate and $0.3 \mathrm{ml}$ of phenylisothiocyanate in isopropyl alcohol and left for 35 minutes to undergo reaction. The resulting solution is dried to complete dryness, dissolved in $0.5 \mathrm{ml}$ of distilled water, centrifuged for 5 minutes and transferred to the device under a pressure of 30 millibars for 5 seconds. Calibration was performed by the standard addition method. The analysis employed aqueous leading electrolyte, containing $0.33 \%$ of boric acid, $0.05 \%$ sodium tetraborate and $0.5 \%$ isopropylalcohol with positive polarity voltage and the length of detection wave - 254 nm. 
The preparation of samples for morphological studies involved commonly used botanical micro methods (Kuseleva and Nenko 2015).

The data were processed statistically using of conventional methods of variation statistics (Dospekhov, 1979; Welham et al., 2014).

Plant resistance to low temperatures in winter was studied in natural conditions and in conditions of induced stress, including forced dehydration and low temperature $\left(-25^{\circ} \mathrm{C}\right)$. The studies were carried out using a filter photometer; MBI-3, MBI-10 and Olympus microscopes; UNICO 2800 and LEKI SS1207 spectrophotometers; Kapel 105 P capillary electrophoresis tool; JW-1-3000 Acom balance and analytic balance; LE-402, Type-310, TsLN-16, Eppendorf 5418R centrifuges; LOIP LB-163 (ТБ-6/24-BK) water bath; SESh-1 drying cupboard; and Gronland refrigerating cabinet.

\section{RESULTS}

All of the analysed varieties showed the lower total and free water content in December 2015 than in December 2014. In the vegetative season of 2015, grape accumulated more macronutrients store in shoots than in 2014. The water con- tent was higher by $13.72 \%$ for the 'Kristall' variety and by 6.1-9.0\% for 'Dostoyniy' and 'Krasnostop AZOS' varieties, respectively (Fig. 1).

In December 2015, compared with 2014, free-water and total water content of 'Kristall' and 'Krasnostop AZOS' was lowered (29.4 and $7.2 \%$, respectively), but slightly higher in 'Dostoyniy' (1.2\%), suggesting more active metabolic behaviour.

During the period of 2012-2015, the free-water content of shoots of 'Kristall' in December was correlated with the maximum air temperature $(\mathrm{r}=0.94)$ and precipitation $(\mathrm{r}=$ 0.92 ), and in 'Dostoyniy' and 'Krasnostop AZOS' varieties - both to maximum and minimum air temperature $(\mathrm{r}=$ 0.65-0.73) and precipitation $(\mathrm{r}=0.66-0.68)$ (Fig. 2).

In December 2015, compared with 2014, the content of chalcones, which protects cell membranes from the breakage (Nenko et al., 2017), increased in the studied grape varieties by $63.7-159.9 \%$ (Fig. 3). Consequently, increase in chalcone content of grape vine is a common pattern for all the studied varieties.

In December 2015, content of starch, which characterises frost resistance in the true dormancy period, was lower in 'Kristall' (1.67 mg/g) and higher 'Dostoyniy' (4.98 mg/g),
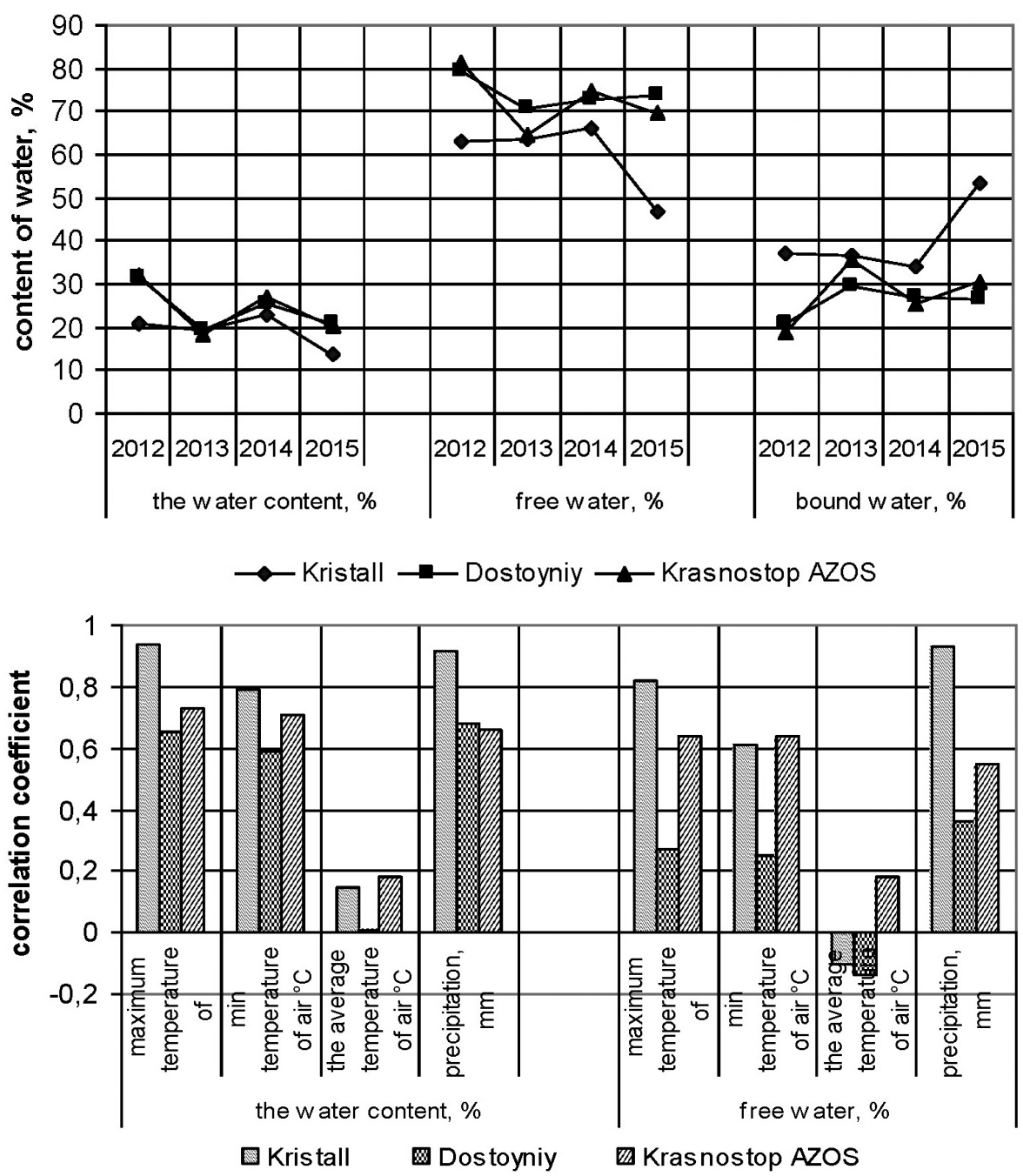

Fig. 1. Moisture status of the grape shoots in December of 2012-2015.

Fig. 2. Correlation of the grape shoot moisture status on 2012-2015 December hydrothermal conditions in the Anapa -Taman zone. 


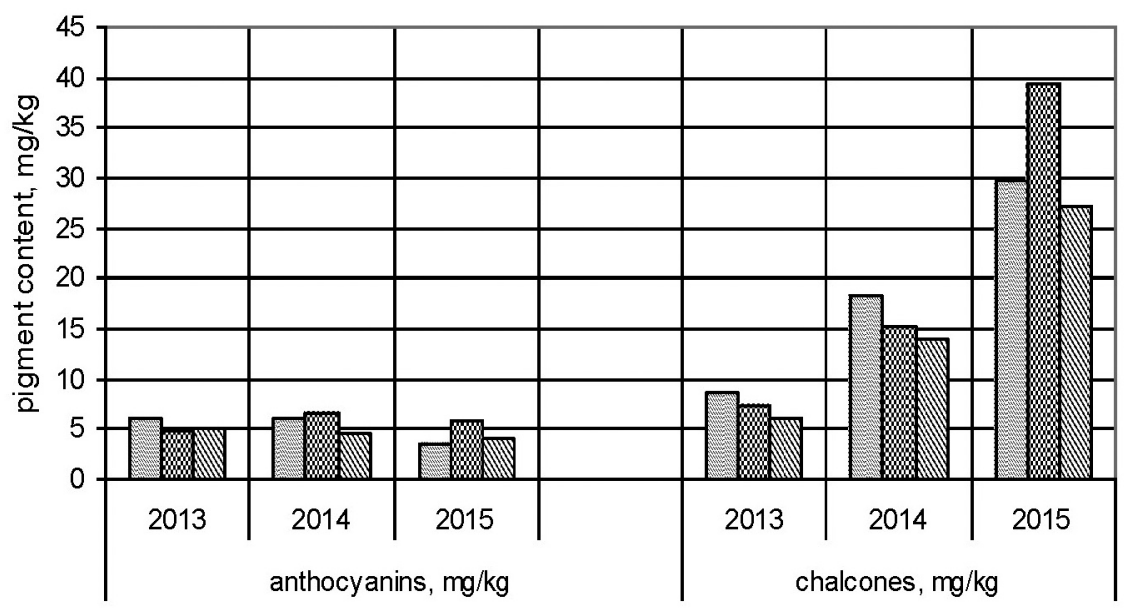

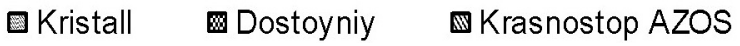

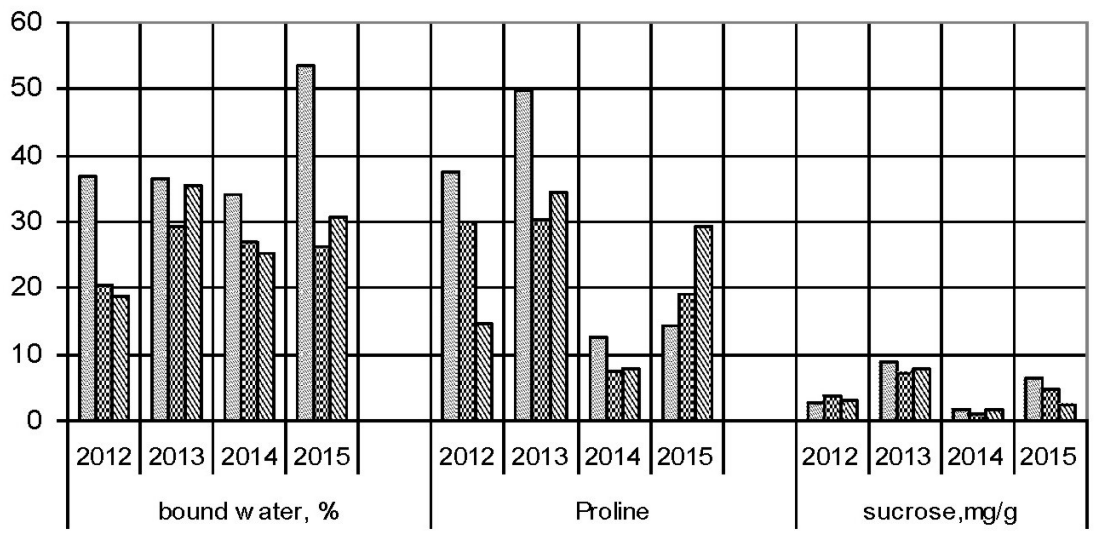

Kristall Dostoyniy Krasnostop AZOS
Fig. 3. Pigment content of grapevine in December 2013-2015.
Fig. 4. Biochemical characteristics of the grape shoot water-retaining capacity in December 2012-2015. while 'Krasnostop AZOS' (4.2 mg/g) had an intermediate position between these. In December 2015, the ratio of sucrose to starch content in 'Kristall' was 3.8, 'Dostoyniy' 0.96 and 'Krasnostop AZOS' - 0.55, characterising 'Kristall' as a more frost-resistant variety. In December 2015 , the bound water content of the grape variety shoots was mostly influenced by sucrose content $(r=0.7)$. In December 2014, the desiccation resistance of the studied varieties was mostly influenced by proline content (in 2013, proline and sucrose), characterising the impact of yearly conditions on protective response to the stressors in the state of true dormancy (Fig. 4).

The study of the mechanism of the grape vine desiccation resistance showed proline to have greater effect and sucrose to have lesser effect bound water contents $(r=0.5)$ in 'Kristall' ( $\mathrm{r}=0.9)$, in 'Krasnostop AZOS' — both proline and sucrose $(\mathrm{r}=0.8)$, and in 'Dostoyniy' — proline and sucrose had slight impact $(\mathrm{r}=0.3)$.

This shows different mechanisms of adaptation to the environment in the studied varieties in the state of true dormancy. For the 2012-2015 period in December, the proline content in 'Kristall' was higher (12.6-49.8 mg/kg), than in 'Krasnostop AZOS' (7.9-34.5 mg/kg) and 'Dostoyniy' (7.6-30.4 mg/kg). In December 2015, 'Kristall' and
'Dostoyniy' varieties had higher contents of ascorbic acid (20.6 and $12.3 \mathrm{mg} / \mathrm{kg}$, respectively) and the phenolcarbonic acids (51.2 and $62.5 \mathrm{mg} / \mathrm{kg}$, respectively), which protect cell membranes from destruction; these values were lower in 'Krasnostop AZOS' $(9.3 \mathrm{mg} / \mathrm{kg}$ and $25.1 \mathrm{mg} / \mathrm{kg}$, respectively) (Fig. 5). Histochemical studies showed starch content to be 5.0 points for the fine-cellular core zone of 'Kristall' and 'Dostoyniy', and 4.7 points for 'Krasnostop AZOS', allowing to characterise these as highly frostresistant. The frost-resistant grape varieties are characterised by the fast hydrolysis of starch already from the beginning of winter. The hydrolysis of starch is delayed in insufficiently frost-resistant varieties.

The content of starch in 'Dostoyniy' in 'Kristall' was 5.0 and 4.9 points, respectively, for December and November of 2015. The starch contents in the shoot fine-cellular core zone did not change in the 'Krasnostop AZOS' variety. Thus, 'Dostoyniy', 'Kristall' showed high winter hardiness, judging from the rates of starch consumption caused by its hydrolysis. 'Krasnostop AZOS' was shown to be frostresistant by the rate of starch consumption. The anatomomorphological study of buds showed them to be in the state of winter dormancy. All of the grapevine varieties had embryonic inflorescences, responsible for the next year yield, embedded in winter buds (eyes). 


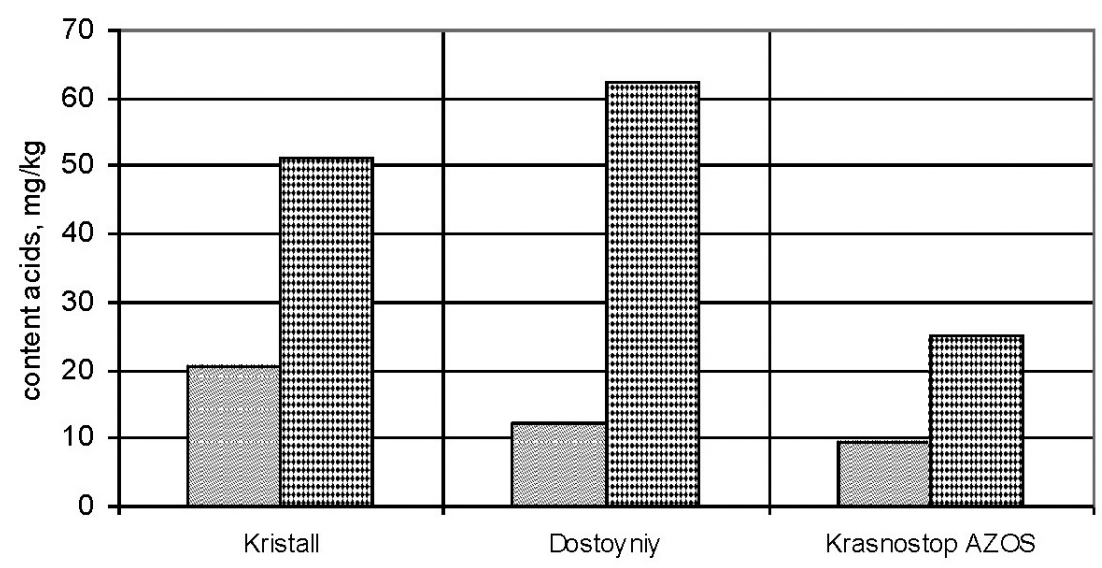

ascorbic acid,mg/kg 田 the amount of coffee and chlorogenic acids, $\mathrm{mg} / \mathrm{kg}$
Fig. 5. Ascorbic and phenolcarbonic acid contents of grape shoots in December 2015.

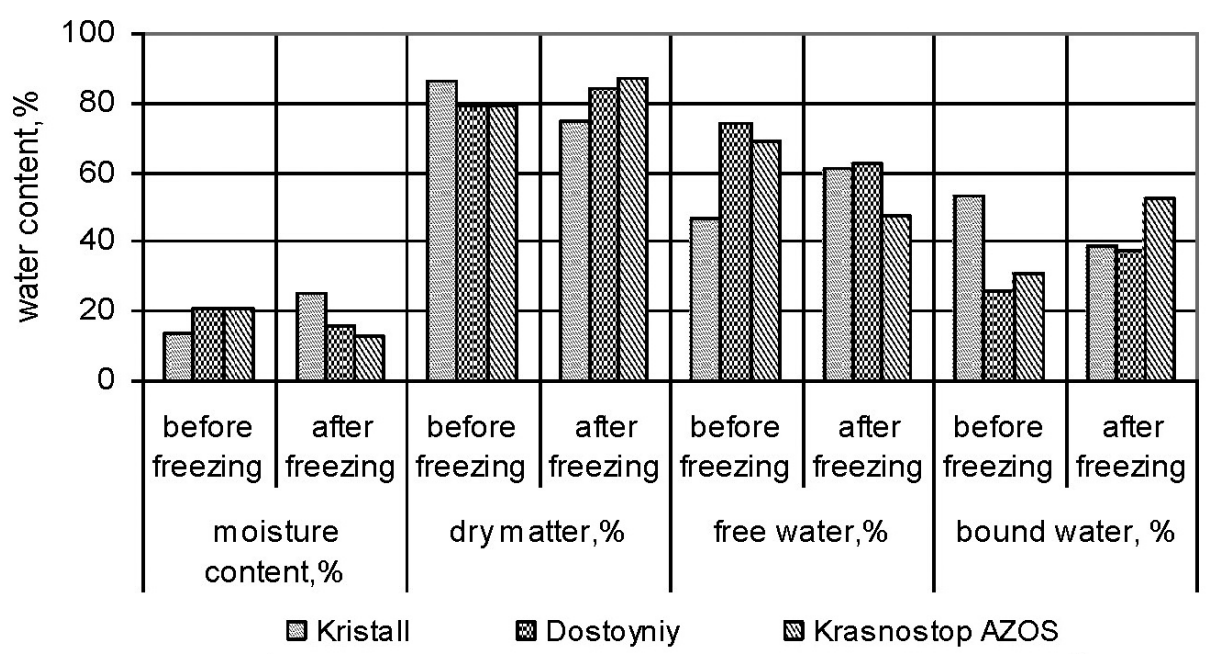

Fig. 6. The impact of the low-temperature stress in a model experiment on the water status of grapevine shoots, December 2015.
The artificial freezing of grapevine shoots in December 2015 at $-25{ }^{\circ} \mathrm{C}$ temperature increased total water content of 'Kristall' shoots by $173 \%$, and in 'Dostoyniy' and 'Krasnostop AZOS' it decreased by 29.9 and $60.3 \%$ (Fig. 6). The free water contents of 'Dostoyniy' and 'Krasnostop AZOS' decreased by 18.2 and $13.8 \%$, respectively. The relative amount of bound water to free water content after freezing was higher by $66.7 \%$ for 'Dostoyniy' and by $45.5 \%$ for 'Krasnostop AZOS', respectively, while the change was insignificant for 'Kristall'. Freezing increased protein content of 'Kristall' $19.9 \%$, decreased in 'Dostoyniy' by $22.1 \%$ and in 'Krasnostop AZOS' variety by $28.6 \%$; starch content in 'Kristall' by $36.5 \%$, and in 'Dostoyniy' and 'Krasnostop AZOS' by 175 and $96.3 \%$, respectively (Fig. 7). This goes to prove active hydrolytic behaviour that agrees with the higher proline content of 'Krasnostop AZOS' variety by $197.6 \%$.

The content of Krebs cycle organic acids in 'Dostoyniy' was $52.2 \%$, and $50.0 \%$ and $17.8 \%$ lower in 'Kristall' and 'Krasnostop AZOS', indicating a decrease in respiration intensity.

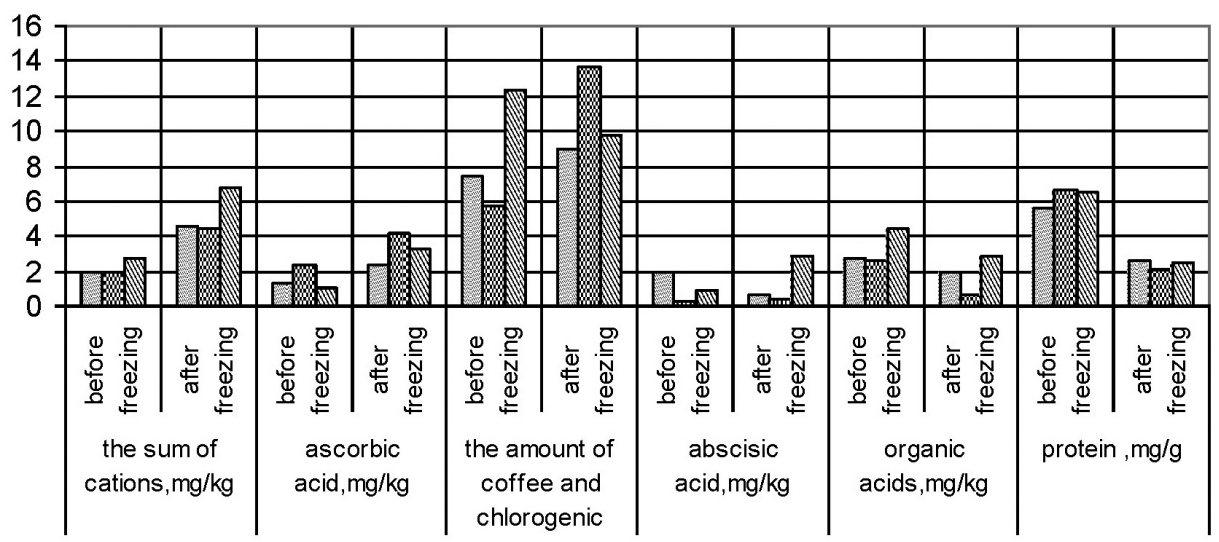

$\square$ Kristall $\quad$ Dostoyniy
$\mathbb{Q}$ Krasnostop AZOS
Fig. 7. Biochemical characteristics of grapevine frost resistance, December 2015. 
The impact of the low-temperature on the content of phenolcarbonic acids in the studied varieties was also assessed. After freezing of shoots, increase in the content of phenolcarbonic acids (chlorogenic, caffeic) occurred in 'Kristall' (by $135.4 \%$ ), in 'Dostoyniy' — by $45.6 \%$ and in 'Krasnostop AZOS' by 6.4 times more. This shows different mechanisms of extremely low-temperature resistance of the varieties, which differ in ecological and geographical origin, in the period of true dormancy.

Histochemical analysis demonstrated that after freezing of the shoots, starch content of the fine-cellular core zone of grape vine in 'Dostoyniy', 'Krasnostop AZOS', 'Kristall' varieties, noted as highly frost-resistant, did not change and continued to be 4.7-5.0 points. Thus, the influence of the low temperatures on the shoots of the studied grape varieties caused the largest changes in the vine cortex and did not damage its core.

In the natural conditions of Anapa and Taman regions the air temperature in January 2015 dropped down to minus $19{ }^{\circ} \mathrm{C}$, which affected adversely plants that were in the state of induced dormancy. In late February 2016, the water content of the shoots increased, compared with December 2015 in 'Kristall' by $12.6 \%$, 'Dostoyniy' - $22.2 \%$, and 'Krasnostop AZOS' - 68.8\%. The free water content in 'Kristall' increased by $53.9 \%$, in 'Dostoyniy' $-7.7 \%$, and in 'Krasnostop AZOS' by $14.8 \%$, due to activation of metabolic processes.

In February 2015, the content of proline in vine increased by 4.1-7.7 times, and the level of starch decreased by 63.65 $\%$ and $49.05 \%$, which is consistent with activation of hydrolytic processes (Fig. 8).

\section{DISCUSSION}

The study was conducted in winter 2012-2016. During this period, the grape plants did not enter the state of deep dormancy and lacked tolerance to extremely low temperatures (second winter-resistance component) (Nenko et al., 2017). This was shown by the high content of free water of the studied varieties, which characterises the intensity of metabolic processes and can be associated with hydrothermal

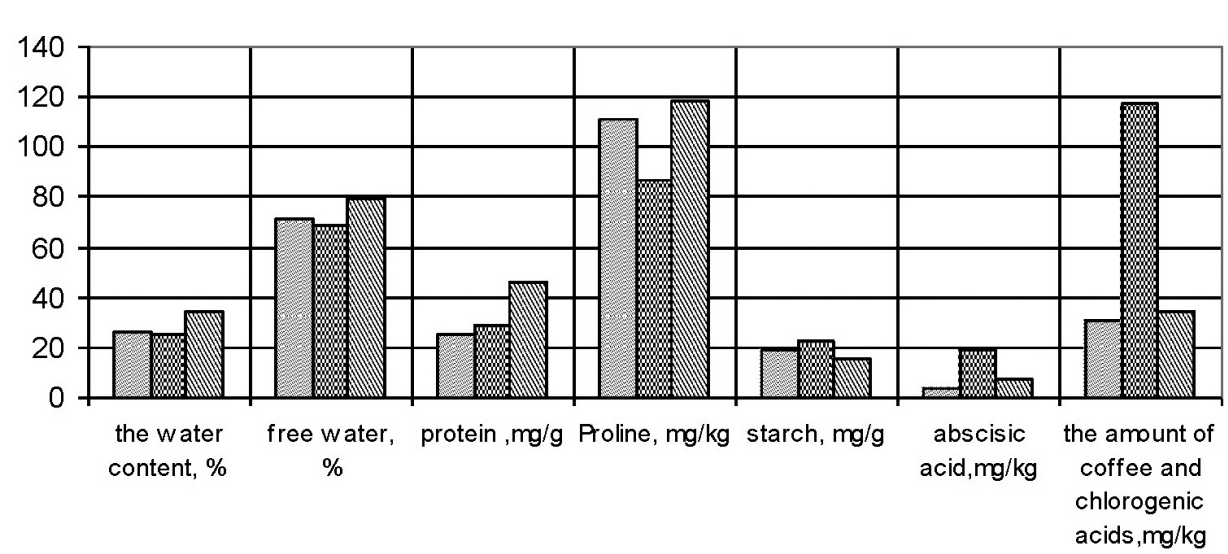

conditions in December 2015 (Kushnirenko and Pecherskaya, 1991). It should be noted the higher content of bound water in the early maturing 'Kristall' suggests that it had better preparation for winter 2015 .

Determination of the content of pigments (anthocyanins and halcons), which are antioxidants that protect cell membranes from destruction (Koshkin, 2010) showed that anthocyanin content was less than for halcons. The biggest difference in their content was observed in 'Krasnostop AZOS' and smallest in 'Kristall', which may be due to the winter hardiness of varieties.

One of the indicators characterising frost resistance in the period of organic rest is starch content and its ability to hydrolyse. The ratio of sucrose to starch in 'Krystall' was 3.8, and in 'Krasnostop AZOS' was 0.55. This parameter also characterises winter hardiness of varieties. The 'Dostoyniy' variety had an intermediate position between these varieties (Nenko et al., 2017).

Winter-hardy varieties are characterised by high content of bound water and great resistance of plant cells to dehydration, imparted by osmoprotectors like proline and sucrose (Jie et al., 2008). Correlation coefficients between the content of the bound water, proline and sucrose showed that in the more winter-hardy 'Kristall', there was higher dependence of bound water on the content of proline, than for the 'Dostoyniy' and 'Krasnostop AZOS'. The accumulation of proline is accompanied by prevention of protein denaturation and preservation of structure and activity of enzymes, which also provide winter hardiness (Koshkin, 2010; Kuznetsov and Shevyakova, 1999).

There was a great influence of the genotype of the grape variety, and its origin, on winter hardiness. The genome of 'Krystall' from Amur grape had a predominant effect on its frost resistance and determined the metabolic processes. The genotype of the winter-hardy variety 'Dzhemete' is present in the pedigree of varieties 'Dostoyniy' and 'Krasnostop AZOS', which determines their winter hardiness. Physiological and biochemical patterns of resistance to low temperatures in these varieties have their own specific features.

Fig. 8. Biochemical characteristics of grape vine on the basis of the third winter-resistance component, February 2016. 
One of the elements of resistance of grape varieties to low temperatures is the resistance of the lipid phase of cell membranes to destruction. A large role in preserving the integrity of the lipid phase is imparted by the water-soluble antioxidant-ascorbic acid, which is able to restore membrane-bound tocopherol, an antioxidant of the lipid phase, which causes a break in the chains of free radical oxidation, interacting with peroxyl and alkoxyl radicals (Foyer et al., 1991; Davey et al., 2000; Koshkin, 2010).

With artificial freezing of shoots of grapes, the content of bound water in varieties 'Dostoyniy' and 'Krasnostop AZOS' increased by 66.7 and $45.5 \%$, respectively, and did not change in the 'Krystall', which may be due to its greater stability. At the same time, hydrolytic processes were activated (the protein and starch content decreased). In 'Krystall' and 'Dostoyniy', the content of phenolcarboxylic acids increased and in 'Krasnostop AZOS' decreased, which may be explained by their ecological and geographical origin. Our results are consistent with the literature, as previously an increase in the concentration of sugar in response to stress caused by low temperature has been shown (Beheshti Rooy et al., 2017). Sugars can enhance the stabilisation of the biomembrane by reducing the freezing temperature of intercellular water (Swanson and El-Shishiny, 1958; Beheshti Rooy et al., 2017).

Under cold stress, the content of abscisic acid, which induces cold resistance genes, increased almost 5-fold in 'Krasnostop AZOS' (Koshkin, 2010). The decrease in the amount of organic acids in the vine of all three varieties after freezing indicated decrease in the intensity of respiration.

In February, all grape varieties had higher contents of phenolcarbonic and ascorbic acids, which are low molecular weight antioxidants, (Koshkin, 2010) preventing the damage of cell membranes, which is consistent with previously published research (Ashraf and Foolad, 2007; Beheshti Rooy et al., 2017). The elevated levels of proline content suggest enhanced water-retaining capacity of cytoplasm (Kuznetsov and Shevyakova, 1999; Koshkin, 2010) and has been used to characterise adaptability in the third winter-resistance component (Nenko et al., 2017). According to literature (Davey et al., 2000; Takahama and Oniki, 2000; Trejo-Martínez et al., 2009), we may assume better resistance of 'Kristall' variety plants to desiccation and formation of proteins is associated with higher proline content, strengthening the cell walls in response to stress factors. Accumulation of proline in response to various stress factors, including low-temperature conditions, has been correlated with stress tolerance. Proline concentration is higher in stress-tolerant than in stress-sensitive plants (Barka and Audran, 1997; Kuznetsov and Shevyakova, 1999).

In the present study, starch and sucrose content was higher in 'Kristall' than in the other varieties, which is consistent with the previously published research (Swanson and ElShishiny, 1958; Zhang et al., 2012). This reflects higher resistance adaptability of 'Kristall' variety to low temperature stress. Our results are consistent with some literature data. For example, elevation of sugar concentration in response to stress induced by low temperature has been shown (Beheshti Rooy et al., 2017. The authors supposed that sugars can increase biomembrane stabilisation through decreasing the freezing point of intercellular water (Wample and Bary, 1992; Beheshti Rooy et al., 2017).

Our results along with literature data (Foyer et al., 1991; Foyer, 1993; Davey et al., 2000; Keilin et al., 2007; Hossain et al., 2014), indicated better adaptation of the 'Kristall' variety to environmental conditions of Anapa and Taman zone, as compared to 'Krasnostop AZOS' and 'Dostoyniy' varieties.

The anatomo-morphological and histochemical studies of the one-year-old plants of the grape varieties in March showed that they has entered the vegetation season, characterised by activity of the growth processes. The starch content of the fine-cellular core zone in 'Dostoyniy', 'Krasnostop AZOS', and 'Kristall' varieties was determined to be 4.9 points. The anatomo-morphological studies of the buds showed that embryonic processes, responsible for the current year yield, had started (Zhang et al., 2012; Kiseleva and Nenko, 2015).

Thus, the obtained results suggested various mechanisms of adaptation of the studied grape varieties to stress factors of winter period, which are typical for the Anapa and Taman zone.

The most informative parameters characterising the resistance of the studied grape varieties to stressors of the 2007-2015 winter periods (water content of shoots, free and bound water contents and their ratio, protein, amino acid proline (Zhang et al., 2012; Kiseleva and Nenko, 2015), sugars, and the content of phenolcarbonic and ascorbic acids (Nenko et al., 2015) are listed in Table 1.

These parameters, indicating physiological and biochemical changes to cold-induced stress could be applied in breeding programmes for grapevine varieties. We assume that the

Table 1

BIOCHEMICAL INDICATORS OF GRAPE INTERSPECIFIC HYBRIDS ADAPTATION TO STRESS FACTORS IN WINTERS OF THE 2007-2015 PERIOD

\begin{tabular}{l|c|c}
\hline \multicolumn{1}{c|}{ Biochemical indicators } & $\begin{array}{c}\text { State of deep } \\
\text { dormancy }\end{array}$ & $\begin{array}{c}\text { State of induced } \\
\text { dormancy }\end{array}$ \\
\hline Water content of shoots, \% & $13.70-31.87$ & $16.44-34.60$ \\
Dry matter content, \% & $68.13-86.28$ & $65.40-83.56$ \\
Free water content, \% & $46.54-81.25$ & $47.5-80.43$ \\
Bound water content, \% & $18.65-53.46$ & $19.85-52.5$ \\
Ratio of bound water to free water & $0.34-1.15$ & $0.24-1.11$ \\
Sucrose content, mg/g & $1.07-11.83$ & $2.18-6.15$ \\
Starch content, mg/g & $1.67-15.24$ & $1.51-8.51$ \\
Proline content, mg/kg & $7.6-92.0$ & $46.2-190.0$ \\
Protein content, mg/g & $2.43-6.58$ & $2.49-8.21$ \\
Content of phenolcarbonic & $0.03-13.4$ & $0.01-0.06$
\end{tabular}

and ascorbic acids, $\mathrm{mg} / \mathrm{g}$ 
above-mentioned parameters could be useful as markers of tolerance to low-temperature conditions in different climatic regions that are relevant for grape growing.

\section{CONCLUSION}

Here we studied the key changes of biochemical and morphological characteristics of grape in the Anapa-Taman zone. The plant response to the different environmental factors showed significant difference in the early maturation period variety 'Kristall', compared to varieties with a medium maturation period ('Dostoyniy' and 'Krasnostop AZOS').

For the interspecific grape hybrids the optimum physiological and biochemical parameters of winter-resistance (in the state of deep and forced dormancy) and the ranges of their variation permit these varieties to survive in extreme conditions of Anapa-Taman zone winter period.

The low-temperature conditions of 2016 causing some subfreezing of grape plants may have effected production performance. In the state of forced dormancy, under the favourable climatic conditions of February 2016, the varieties may be characterised positively by the third winterresistance component.

Our study indicated significant differences between studied grape varieties in their ability to adapt to hydrothermal conditions of the Russian South. The results of the study can be used to monitor frost-resistance of the grape plants for agricultural and breeding purposes.

\section{REFERENCES}

Arun-Chinnappa, K. S., Ranawake, L., Seneweera, S. (2017). Impacts and management of temperature and water stress in crop plants. In: Minhas, P., Rane, J., Pasala, R. (eds.). Abiotic Stress Management for Resilient Agriculture. Springer, Singapore, pp. 221-233.

Ashraf, M., Foolad, M. R. (2007). Roles of glycine betaine and proline in improving plant abiotic stress resistance. Environ. Exper. Bot., 59, 206-216.

Barka, E. A., Audran, J. C. (1997). Response of champenoise grapevine to low temperatures: Changes of shoot and bud proline concentrations in response to low temperatures and correlations with freezing tolerance. $J$. Horticult. Sci., 72, 577-582.

Beheshti Rooy, S. S., Hosseini Salekdeh, G., Ghabooli, M., Gholami, M., Karimi, R. (2017). Cold-induced physiological and biochemical responses of three grapevine cultivars differing in cold tolerance. Acta Physiol. Plant., 39, 264.

Davey, M. W., Montagu, M., Inze, D., Sanmartin, M., Kanellis, A., Smirnoff, N., Benzie, I. J. J., Strain, J. J., Favell, D., Fletcher, J. (2000). Plant L-ascorbic acid: Chemistry, function, metabolism, bioavailability and effects of processing. J. Sci. Food Agricult., 80, 825-860.

Dospekhov, V. А. (1979). Methods of a Field Experiment. [Доспехов, Б. А. Методика полевого опыта.] Kolos, Moscow. 416 pp.

Ferrandino, A., Lovisolo, C. (2014). Abiotic stress effects on grapevine (Vitis vinifera L.): Focus on abscisic acid-mediated consequences on secondary metabolism and berry quality. Environ. Exper. Bot., 103, 138-147.

Foyer, C. H., Lelandais, M., Edwards, E. A., Mullineaux, P. (1991). The role of ascorbate in plants, interactions with photosynthesis, and regulatory significance. In: Pell, E., Steffen, K. (eds.) Active Oxygen. Oxidative Stress and Plant Metabolism. American Society of Plant Physiologists, Rockville, pp. 131-144.

Foyer, C. H. (1993). Ascorbic acid. In: Alscher, R. G., Hess, J. L. (eds.). Antioxidants in Higher Plants. CRC Press, Boca Raton, pp. 32-57.

Hossain, M. A., Hoque, M. A., Burritt, D. J., Fujita, M. (2014). Proline protects plants against abiotic oxidative stress: Biochemical and molecular mechanisms. Oxidative Damage to Plants, 5, 477-522.

Jie, Y., Yang, H., Zhao, H., Zhang, W., Li, D. (2008). Promotion of proline accumulation in apple leaves by bioregulators. Acta Hortic., 774, 237-242.

Keilin, T., Pang, X., Venkateswari, J., Halaly, T., Crane, O., Keren, A., Ogrodovitch, A., Ophir, R., Volpin, H., Galbraith, D., Or, E. (2007). Digital expression profiling of a grape-bud EST collection leads to new insight into molecular events during grape-bud dormancy release. Plant Sci., 173, $446-457$.

Kiseleva, G. K, Nenko, N. I. (2015). Anatomical, morphological and histochemical evaluation of vegetative organs of fruit crops and grapevine. In: Modern Instrumental and Analytical Methods of the Fruit Crops and Grapevine Research. [Киселева, Г. К., Ненько, Н. И. Анатомическая, морфологическая и гистохимическая оценка вегетативных органов плодовых культур и винограда. В кн.: Современные инструментальные и аналитические методы исследования плодовых культур и винограда.] North-Caucasian Regional Research Institute of Horticulture and Viticulture, Krasnodar, pp. 32-39.

Koshkin, E. I. (2010). Physiology of Stability of Agricultural Crops. [Кошкин, Е. И. Физиология устойчивости сельскохозяйственных культур.] Drofa, Moscow.

Kushnirenko, M. D., Pecherskaya, S. N. (1991). Physiology of the Plants Water Exchange and Drought Resistance. [Кушниренко, М. Д., Печерская, С. Н. Физиология водообмена и засухоустойчивости растений.] Shtiintsa, Kishinev. 306 pp.

Kuznetsov, V. V., Shevyakova, N. I. (1999). Proline under stress: Biological role, metabolism, regulation. [Кузнецов, В. В., Шевякова, Н. И. Пролин при стрессе: биологическая роль, метаболизм, регуляция.] Physiol. Plants [Физиология растений], 46, 321-336.

Nenko, N. I., Ilina, I. A., Kiseleva, G. K., Sundyreva, M. A. (2015). Physiological and biochemical parameters of resistance of grape varieties to the stressors of the winter period in the South of Russia. [Ненько, Н. И., Ильина, И. А., Киселева, Г. К., Сундырева, М. А. Физиологические и биохимические параметры устойчивости винограда к стрессорам в зимнего периода на Юге России.] Yale J. Sci. Educ. [Йельский журнал науки и образования], 1 (16), 587-598.

Nenko, N. I., Petrov, V. S., Ilyina, I. A., Kisileva, G. K., Sundyreva, M. A., Sokolova, V. V. (2017). The physiological and biochemical mechanisms of adaptation to the low-temperature stresses of the grape varieties different in ecological and geographical origin. [Ненько, Н. И., Петров, В. С., Ильина, И. А., Киселева, Г. К., Сундырева, М. А., Соколова, В. В. Физиологические и биохимические механизмы адаптации к низкотемпературному стрессу винограда различных сортов в различных различных экологических и географических районах.] Horticult. Vinicult. [Садоводство и виноградарство], 5, 33-38.

Ollat, N., van Leeuwen, C., Garcia de Cortazar-Atauri, I., Touzard, J.-M. (2017). The challenging issue of climate change for sustainable grape and wine production. OENO One, 51, 59?60.

Sha Valli Khan, P. S., Nagamallaiah, G. V., Dhanunjay Rao, M., Sergeant, K., Hausman, J. F. (2014). Emerging Technologies and Management of Crop Stress Tolerance. Academic Press, San Diego. 544 pp.

Swanson, C. A., El-Shishiny, E. D. H. (1958). Translocation of sugars in the Concord grape. Plant Physiol., 33, 33-37.

Takahama, U., Oniki, T. (2000). Flavonoides and some other phenolics as substrates of peroxidase: Physiological significance of the redox reactions. Plant Res., 133, 301-309. 
Trejo-Martínez, M. A., Orozco, A., Almaguer-Vargas, G., Carvajal-Millįn, E., Gardea, A. A., (2009). Metabolic activity of low chilling grapevine buds forced to bud break. Thermochim. Acta, 481, 28-31.

Wample, R. L., Bary, A. (1992). Harvest date as a factor in carbohydrate storage and cold hardiness of Cabernet Sauvignon grapevines. J. Amer. Soc. Hort. Sci., 117 (1), 32-36.

Welham, S. J., Gezan, S. A., Clark, S. J., Mead, A. (2014). Statistical Methods in Biology: Design and Analysis of Experiments and Regression. Chapman and Hall/CRC, New York. 608 pp.

Xian, M., Luo, T., Khan, M. N., Hu, L., Xu, Z. (2017). Identifying differentially expressed genes associated with tolerance against low temperature stress in brassica napus through transcriptome analysis. Int. J. Agricult. Biol., 19, 273-281.

Yakuba, Yu. F., Ilyina, I. A., Zakharova, M. V., Lifar G. V. (2015). The methodology to determine mass concentration of tartaric, malic, succinic, citric acids in the shoots and leaves of fruit crops and grape-vine with the use of capillary electrophoresis. [Якуба, Ю. Ф. Ильина, И. А., Захарова, Г. В., Лифарь, П. М Методика определения массовой концентрации винной, яблочной, янтарной, лимонной кислот в побегах и листьях плодовых культур и винограда с применением капиллярного электрофореза.] In: Modern Instrumental and Analytical Methods of the Fruit Crops and Grapevine Research. NCRRIH\&V, Krasnodar, pp. $68-79$

Yegorov, E. A., Shadrina, Zh. A., Kochyan, G. A. (2017). The model and mechanism of the resource conservation processes management in industrial fruit farming and viniculture. [Егоров, Е. А., Шадрина, Ж. А., Кочьян, Г. А. Модель и механизм рационального использование ресурсов в промышленном плодоводстве и виноделии.] Acad. Papers NCRRIH\&V, 12, 7-12.

Yermakov, A. I., Arasimovich, V. E., Smirnova-Ikonnikova, M. I., Yarosh, N. P., Lukovnikova, G. A. (1972). Methods for Biochemical Study of Plants. [Ермаков, А. И., Арасимович, В. В., СмирноваИконникова, М. И., Яриш, Н. П., Луковникова, Г. А. Методы биохимического исследования растений.] Kolos Leningrad Department, Leningrad. $456 \mathrm{pp}$.

Zhang, J., Wu, X., Niu, R., Liu, Y., Liu, N., Xu, W., Wang, Y. (2012). Cold-resistance evaluation in 25 wild grape species. Vitis, 51 (4), 153-160.

Received 17 July 2018

Accepted in the final form 25 September 2018

\section{TOLERANCE ZEMO TEMPERATŪRU STRESAM VĪNOGU ŠĶIRNĒM AR DAŽĀDU EKOLOĢISKO UN ĢEOGRĀFISKO IZCELSMI}

Tika pētītas biok̦īmiskas un morfoloğiskas izmaiņas vairākām vīnogu šķirnēm ārējo apstākḷu ietekmē Anapas-Tamaņas regíionā Ziemeḷkaukāzā. Üdens saturs dzinumos, proteīnu, prolīna, cukuru un askorbīnskābes līmenis ir galvenie indikatori, kas raksturo augu salcietību. Dažādas izcelsmes škirnes uzrāda atškirīgu spēju pielāgoties reǵiona apstākliiem. 